\title{
COMPARISON OF AEROBIC AND ANAEROBIC STABILITY INDICES THROUGH A MSW BIOLOGICAL TREATMENT PROCESS
}

Sergio Ponsá ${ }^{(1)}$, Teresa Gea ${ }^{(1)}$, Llorenç Alerm ${ }^{(2)}$ Javier Cerezo $^{(3)}$ and Antoni Sánchez ${ }^{(1)}$ **

(1) Composting Research Group

Department of Chemical Engineering

Escola Tècnica Superior d'Enginyeria

Universitat Autònoma de Barcelona

08913-Bellaterra (Barcelona), Spain.

(2) Entitat Metropolitana de Serveis Hidràulics i Tractament de Residus

Carrer 62 núm 16-18 Edifici B. Zona Franca.

08040-Barcelona, Spain

(3) Ecoparc del Besòs SA

Polígon Industrial Can Salvatella

Zona de Can Cabanyes

08110-Montcada i Reixach (Barcelona), Spain

* Corresponding author: Antoni Sánchez

Phone: 34-93-5811019

Fax: $\quad 34-93-5812013$

E-mail address: antoni.sanchez@uab.cat 


\begin{abstract}
A complex mechanical-biological waste treatment plant designed for the processing of mixed municipal solid wastes (MSW) and source-selected organic fraction of municipal solid wastes (OFMSW) has been studied by using stability indices related to aerobic (respiration index, RI) and anaerobic conditions (biochemical methane potential, BMP). Several selected stages of the plant have been characterized: waste inputs, mechanically treated wastes, anaerobically digested materials and composted wastes, according to the treatment sequence used in the plant. Results obtained showed that the main stages responsible for waste stabilization were the two first stages: mechanical separation and anaerobic digestion with a diminution of both RI and BMP around 40 and $60 \%$, respectively, whereas the third stage, composting of digested materials, produced a smaller biological degradation (20-30\%). The results related to waste stabilization were similar in both lines (MSW and OFMSW), although the indices obtained for MSW were significantly lower than those obtained for OFMSW, which demonstrated a high biodegradability of OFMSW. The methodology proposed can be used for the characterization of organic wastes and the determination of the efficiency of operation units used in mechanical-biological waste treatment plants.
\end{abstract}

Keywords: Biochemical methane potential, Mechanical-Biological treatment plant, Municipal Solid Wastes, Organic Fraction of Municipal Solid Wastes, Respiration index. 


\section{Introduction}

The bulk municipal solid waste stream (MSW, which can contain a range of 35-50\% of organic materials) and the source-selected organic fraction of municipal solid waste (OFMSW, with an organic content over $80 \%$ ) have deserved special attention from the European authorities. As a result, at present there is an increasing number of facilities such as composting, anaerobic digestion and mechanical-biological treatment plants whose main goal is to reduce the biodegradable organic matter content of these organic wastes and stabilize them by means of biological processes.

The analysis of waste treatment efficiency in these plants requires a reliable measure of the biodegradable organic matter content of organic wastes and thus, their stability defined as the extent to which readily biodegradable organic matter has decomposed (Lasaridi and Stentiford, 1998). This measure would permit the evaluation of current working plants, the improvement of the biological treatment process, the design of optimized facilities and the potential environmental impact of the final products.

Some biochemical parameters such as volatile solids (VS), total and dissolved organic carbon (TOC, DOC) and chemical oxygen demand (COD) have been used to monitor the evolution of biological processes (Fontanive et al., 2004; Komilis and Ham, 2003; Papadimitriou and Balis, 1996; Ros et al., 2006). These parameters lack precision when determined on heterogeneous materials such as MSW or OFMSW because of the presence of non-biodegradable volatile or oxidizable materials.

Biological activity measurements have been widely suggested in literature as a measure of biodegradable organic matter content or stability. In this sense, aerobic respirometric techniques and methanogenic activity assays have been proposed (Adani et 
al., 2004; Barrena et al., 2006; Hansen et al., 2004; Ianotti et al., 1993; Ligthart and Nieman, 2002; Scaglia et al., 2000; Tremier et al., 2005). The suggested methodologies differ in key assay parameters such as temperature, which is directly related to the biological activity rate. Indeed, changes in the optimum temperature value have been reported for maximum biological activity determination through the composting process evolution (Barrena et al., 2005; Lasaridi et al., 1996). Some comparisons between a few of the proposed aerobic methods have been made (Adani et al., 2003; Adani et al., 2006; Gea et al., 2004), concluding that respirometric indices are suitable for biological process monitoring. On the other hand, only one recent reference (Cossu and Raga, 2007) have presented a good correlation between an accumulative aerobic respiration method and the biogas potential for landfill excavated waste. Furthermore, a number of standards have been already proposed (ASTM, 1996; Cooper, 2005; US Department of Agriculture and US Composting Council, 2001). Notwithstanding the amount and quality of the work referred, there is no consensus for stability measurements within the research community in the solid waste treatment field (Barrena et al., 2006).

Some of the above mentioned methods have been considered in the European legislation drafts (European Commission, 2001) and adopted in national regulations by some European countries such as Germany (Federal Government of Germany, 2001), Italy (Favoino, 2006) or England and Wales (Godley et al., 2005). Table 1 shows the test conditions for some of the national standards defined for biological stability determination under aerobic and anaerobic conditions and the proposed stability limits. As can be observed, the methodologies proposed differ in many key aspects such as the use of an inoculum, the amount of sample to be used and its preparation, the assay temperature (mesophilic or thermophilic) or the test duration. Even the expression of the results (oxygen 
uptake rate or cumulative consumption) and the units (dry or volatile solids basis) are different among the test published.

The objectives of this research are therefore: i) to study the suitability of the aerobic respiration index and the methane potential for the determination of the biodegradable organic matter content and biological stability in samples from a selected MBT plant (Ecoparc de Montcada, Barcelona, Spain), which were obtained at different stages of their biodegradation process; ii) to compare the two indices proposed (aerobic and anaerobic), iii) to determine the correlations among the methods studied and, iv) to determine the efficiency of the treatment of biodegradable organic matter in the evaluated MBT plant, based on the selected indices.

\section{Materials and Methods}

\subsection{Materials}

Samples were obtained from a Mechanical-Biological Treatment (MBT) plant (Ecoparc de Montcada, Montcada i Reixach, Barcelona) that treats mixed MSW (63 $\pm 11 \%$ dry matter content, $63 \pm 12 \%$ volatile solids content) and source-selected organic fraction of MSW (OFMSW) (39 $\pm 5 \%$ dry matter content, $67 \pm 11 \%$ volatile solids content). Samples were collected during April-May 2006. Analytical methods were carried out on a representative sample (approximately $20 \mathrm{~kg}$ ) obtained by mixing four subsamples of about $5 \mathrm{~kg}$ each, taken from different points of the bulk of material. 


\subsection{Mechanical-Biological treatment plant}

The MBT plant studied is located in Montcada (Barcelona, Spain) and it is denominated Ecoparc de Montcada. Mixed MSW and source-selected organic fraction of municipal solid wastes (OFMSW) consisting of kitchen and garden wastes coming from the Metropolitan Area of Barcelona are treated in this plant. MSW and OFMSW are treated separately in two independent lines. The capacity of the plant is 240,000 t/year $(70,000$ t/year of OFMSW and 170,000 t/year of MSW). A schematic diagram of the MBT plant and the sampling points is shown in Figure 1. The treatment of wastes includes 3 main phases:

Step 1: Mechanical pretreatment: Both OFMSW and MSW are treated to remove inorganic materials such as plastics, metal, glass and stones, which are recycled. The mechanical pretreatment includes: trommel screens (to remove large impurities), magnetic separator (to remove ferric materials), Foucault separator (to remove aluminum), ballistic separator (to remove large density materials) and a shredder. After this pretreatment sequence the organic materials are essentially free of inorganic contaminants.

Step 2: Anaerobic digestion: organic matter is anaerobically digested in 3 digesters of 4,500 $\mathrm{m}^{3}$ of capacity. The plant uses the Valorga process (Bonhomme and Pavia, 1986), in which the material is processed in solid state and under mesophilic conditions $\left(38^{\circ} \mathrm{C}\right)$. Mixing is provided by biogas injection along the reactor. Retention time is set at 21 days.

Step 3: Composting: Material coming from anaerobic digesters is mixed with bulking agent (pruning wastes in a ratio 2:1) and composted in a tunnel composting system (17 tunnels) during three weeks to stabilize and sanitize the material. During this period, operational 
parameters (temperature, oxygen and moisture content) are monitored and controlled. Final compost (from OFMSW) or stabilized waste (from MSW) is stockpiled before commercialization.

Samples were collected from the most significant points of the MBT plant (Figure 1), and for both lines (MSW and OFMSW). The samples selected for the study of the plant were: input material, pretreated material, digested material, composted material and final material (compost or stabilized waste), which resulted in 10 samples (5 for each line). Samples were immediately frozen and conserved at $-20^{\circ} \mathrm{C}$ after collection. Before analysis, samples were thawed at room temperature for 24 hours.

\subsection{Analytical methods}

Water content, dry matter and organic matter or volatile solids (OM or VS) were determined according to the standard procedures (U.S. Department of Agriculture and U.S. Composting Council, 2001).

\subsection{Respirometric tests}

A static respirometer was built according to the original model described previously (Ianotti et al., 1993) and following the modifications and recommendations given by the U.S. Department of Agriculture and U.S. Composting Council (2001). A detailed description of the respirometer can be found elsewhere (Barrena et al., 2005). Approximately $250 \mathrm{~mL}$ of sample were placed in $500 \mathrm{~mL}$ Erlenmeyer flasks on a nylon mesh screen that allowed air movement under and through the solid samples. The setup 
included a water bath to maintain the temperature at $37^{\circ} \mathrm{C}$ during the respirometric test. Prior to the assays, samples were incubated for 24 hours at $37^{\circ} \mathrm{C}$. During all the incubation period samples were aerated with previously humidified air at the sample temperature. The drop of oxygen content in a flask containing a sample was monitored with a dissolved oxygen meter (Lutron 5510, Lutron Co. Ltd., Taiwan) connected to a data logger. The rate of respiration of the sample (Oxygen Uptake Rate, OUR, based on dry matter content) was then calculated from the slope of oxygen level decrease according to the standard procedures (Ianotti et al., 1993). Results of the static respirometric index are expressed as $g$ of oxygen consumed per $\mathrm{kg}$ of dry matter and per hour and are presented as an average of three replicates.

\subsection{Biochemical methane potential}

$200 \mathrm{~g}$ of a wet representative waste sample were used in this test. Sample was mixed in a weight ratio 1:1 with an inoculum coming from the output of the anaerobic digester of the MBT plant except for fresh input OFMSW and MSW samples where a weight ratio 10:1 of inoculum:sample was used to avoid acidification and inhibition caused by volatile fatty acids accumulation. No water was added to this mixture except for final dry samples (compost and stabilized MSW) to reach a minimum moisture content of $40 \%$.

The mixture was incubated in a water bath at $37^{\circ} \mathrm{C}$ in a sealed aluminum bottle with a working volume of $1 \mathrm{~L}$. Before each experiment, the bottles were purged with nitrogen gas to ensure anaerobic conditions. The bottle was provided with a ball valve connected to a pressure digital manometer, which allowed the determination of the biogas pressure. The bulk density of the mixture was determined in triplicates in order to calculate the headspace 
volume of the bottles. During the test, the bottles were shaken once a day. The results on biogas production were obtained from the pressure in the bottle and the headspace volume. Excessive pressure in the bottle was released by purging the biogas produced (25-30 times during the experiment). Biogas composition was also routinely measured.

The tests were carried out in triplicate and the results obtained at 21 days $\left(\mathrm{BMP}_{21}\right)$ and at the end of the test when no significant biogas production was detected $\left(\mathrm{BMP}_{\mathrm{F}}\right)$ are expressed as biogas volume (L) produced and measured at normal conditions $(\mathrm{T}=273 \mathrm{~K}$, $\mathrm{P}=1$ bar) per kg of dry matter. A triplicate measure of the biogas production of the inoculum was carried out as a blank and deducted from the biogas production of the waste samples. The deviation found for inoculum biogas production was low (10\%). Biogas production in 21 days $\left(\mathrm{BMP}_{21}\right)$ for the inoculum used was within $60-70 \mathrm{~L}$ of biogas per dry $\mathrm{kg}$ of inoculum. In fact other standardized methods recommend a minimum level activity of the inoculum in order to obtain good results (Federal Government of Germany, 2001).

Biogas composition was analyzed by gas chromatography (Perkin-Elmer AutoSystem XL Gas Chromatograph) with a thermal conductivity detector and using a column Hayesep 3m 1/8" 100/120. Volatile fatty acids (VFA) were determined by gas chromatography (Perkin-Elmer AutoSystem XL Gas Chromatograph) with a flame ionization detector (FID) and a column HP Innowax $30 \mathrm{~m} \times 0.25 \mathrm{~mm} \times 0.25 \mu \mathrm{m}$. The details of biogas and VFA analysis can be found elsewhere (Fernández et al., 2005). Typical values of methane percentage in biogas were around 55-65\%, whereas VFA were not detected. 


\section{Results and discussion}

\subsection{Respirometric study}

The results of the evolution of respiration index for OFMSW and MSW treatment lines in MBT plant are shown in Figure 2. The values presented of RI and BMP are expressed on a dry matter basis, because content of the samples varied significantly as biodegradation process occurred (Barrena et al., 2005). Organic matter basis has been exclusively used in the expression of final materials stability for comparison with some national stability limits.

Similar evolution trends can be observed for both lines, indicating a progressive stabilization of the material. In general, respiration indices found for OFMSW are higher than those of MSW, which is expected since OFMSW contains a higher content of labile organic compounds. It is important to note that these differences are more significant in initial samples (input and materials mechanically pretreated), whereas the differences are minimal after biological treatment (digested and composted materials), when labile organic matter has been biodegraded.

Specific results from the main steps in the studied MBT are presented in Table 2. These results indicate that there is a significant loss of biodegradable organic matter in the mechanical pretreatment (43\% for OFMSW and $28 \%$ for MSW, respectively). This fact is somewhat surprising since mechanical pretreatment occurs in a short time (no more than two days). It is probable that the sequence of operations used in mechanical pretreatment (several trommel screens and separators) favors the presence of oxygen and acts as an aerobic biodegradation process. As the mechanical pretreatment is an essential part of a 
MBT plant, it can be concluded that the loss of biodegradable organic matter in this part of the process should be considered in future MBT designs, especially when estimating the efficiency of the next steps, for instance, potential biogas production for anaerobic digestion or aeration requirements for composting. In any case, mechanical pretreatment should be the focus of future studies.

After mechanical pretreatment, the reduction of RI observed in anaerobic digestion is also very high (Table 2). In fact, anaerobic digestion is the main step regarding biodegradable organic matter reduction for both OFMSW and MSW. The reductions of RI observed show that a considerable part of aerobically biodegradable organic matter can be anaerobically digested. The values observed are in accordance with volatile solids reductions found for anaerobic digesters at laboratory (Fernández et al., 2005) and industrial scale (Fruteau et al., 1997; Lissens et al., 2001; Luning et al., 2003). Finally, composting contributed to organic matter stabilization in a $33 \%$ and $38 \%$ for OFMSW and MSW, respectively (Table 2).

In any case, the methodology proposed in this work can be of interest for application in any configuration of waste treatment plant to identify the most important operations related to organic matter stabilization and efficiency. Since there is no evidence on other published works with different technologies or treatment sequences, further studies are necessary to determine the optimal configuration for MBT plants.

\subsection{Methane potential study}

The results obtained for the Biochemical Methane Potential at 21 days $\left(\mathrm{BMP}_{21}\right)$ are shown in Figure 3 for OFMSW and MSW. $\mathrm{BMP}_{21}$ for OFMSW shows a parallel evolution 
to RI (Figures 2 and 3). Again, there is a considerable loss of methane potential in mechanical pretreatment, and the role of anaerobic digestion is prevalent in organic matter stabilization, whereas the third step in the process, composting, acts as a final stabilization process (Table 2). However, the results of $\mathrm{BMP}_{21}$ obtained for MSW appear to be more erratic. As expected, there is a large reduction of methane potential in anaerobic digestion (71\%, Table 2), which again indicates the importance of this process in a combined anaerobic-aerobic MBT plant. However, a reduction of $\mathrm{BMP}_{21}$ in mechanical pretreatment or composting is not observed. A possible explanation is that the time spent in these operations does not permit the degradation of organic matter in a less biodegradable material such as mixed MSW.

\subsection{Correlation among stability indices}

\subsubsection{Duration of BMP test}

In this work, several samples from the treatment of OFMSW were analyzed in terms of BMP obtained at 21 days and final BMP obtained when biogas production was not detected (more than 100 days). Results are shown in Figure 4. Although the dispersion is high, the correlation between $\mathrm{BMP}_{21}$ and $\mathrm{BMP}_{\mathrm{F}}$ was highly significant with a correlation ratio of 0.9998 and a slope of 0.729 . According to these results, methane produced during 21 days corresponds to the $73 \%$ of ultimate potential methane. Although no values have been found for solid wastes, this value is similar to those used for the characterization of wastewater biodegradability by means of biochemical oxygen demand (Metcalf and Eddy, 2003). According to this test, the ratio $\mathrm{DBO}_{5} / \mathrm{DBO}_{\mathrm{F}}$ is within the range of $60-70 \%$. Another value of interest obtained in this experiment is the determination of total methane potential 
for OFMSW, which resulted in $572 \mathrm{~L}$ biogas per dry Kg of OFMSW, with a percentage of methane of $60 \%$. This value is in accordance with other values found for food wastes (Eleazer et al., 1997) and source-separated municipal solid waste (Hansen et al., 2003).

\subsubsection{Aerobic and anaerobic indices}

Correlation between RI (aerobic) and $\mathrm{BMP}_{21}$ (anaerobic) is presented in Figure 5 for all the samples analyzed (including MSW and OFMSW samples). A linear correlation between RI and $\mathrm{BMP}_{21}$ with a slope of 54.0 can be obtained, with a high level of statistical significance (correlation coefficient: 0.94, $\mathrm{p}<0.0001$ ). This is an indication that both indices are suitable to predict waste stability, although from a practical point of view, respiration index is more recommendable in terms of time required, no need of seed, etc. Thus, aerobic indices could be used for the monitoring of the degree of degradation in anaerobic processes in waste treatment plants. Although some correlations between aerobic indices have been reported (Adani et al., 2003), this is, to our knowledge, one of the first studies where aerobic and anaerobic stability indices are correlated for organic solid wastes in different stages of biodegradation.

\subsection{Final materials stability}

Values of RI and $\mathrm{BMP}_{21}$ for the final materials (compost from OFMSW and stabilized material from MSW) are presented in Table 3. RI and $\mathrm{BMP}_{21}$ in Table 3 are expressed in dry matter basis and organic matter basis, since some national regulations on stability use organic matter (often expressed as volatile solids) as the basis for stability 
measurements (Table 1). As can be seen in Table 3, values obtained for stabilized material sampled from the mixed MSW treatment line are very close to those proposed in different national regulations, being respiration index $1.19 \mathrm{~g} \mathrm{O}_{2} \mathrm{~kg} \mathrm{VS}^{-1} \mathrm{~h}^{-1}$ for a limit of $1 \mathrm{~g} \mathrm{O}_{2} \mathrm{~kg}$ $\mathrm{VS}^{-1} \mathrm{~h}^{-1}$ proposed in Italian regulation, and $26 \mathrm{~L} \mathrm{~kg} \mathrm{DM}^{-1}$ for the biogas production when the limit proposed in German legislation is $20 \mathrm{~L} \mathrm{~kg} \mathrm{DM}^{-1}$.

The values of stability obtained for compost from source-selected OFMSW are, on the contrary, far from those presented in some national regulations and in $2^{\text {nd }}$ Draft of Biological Treatment of Biowaste (European Commission, 2001). Thus, respiration index is $2.11 \mathrm{~g} \mathrm{O}_{2} \mathrm{~kg} \mathrm{VS}^{-1} \mathrm{~h}^{-1}$ (the proposed limit is $1 \mathrm{~g} \mathrm{O}_{2} \mathrm{~kg} \mathrm{VS}^{-1} \mathrm{~h}^{-1}$ ) and the biogas production is $38 \mathrm{~L} \mathrm{~kg} \mathrm{DM}^{-1}$ (the proposed limit is $20 \mathrm{~L} \mathrm{~kg} \mathrm{DM}^{-1}$ ). It appears that composting time in the MBT plant should be extended for a more effective compost stabilization. Nevertheless, it should be kept in mind that the limits proposed in most of the regulations are intended for stabilization of mixed MSW prior to landfilling or incineration, which is not the case of the MBT plant studied.

\section{Conclusions}

The study carried out has demonstrated that the methodology proposed can be used for the monitoring of stabilization of organic matter in mechanical-biological waste treatment plants. Both aerobic and anaerobic indices can be used for the estimation of the biodegradable organic matter content of solid waste samples and the correlation between both indices is good. However, aerobic indices are recommended because of the shorter duration of the assay. 


\section{Acknowledgements}

The authors wish to thank the interest and help received from people of Ecoparc de Montcada, especially from Alberto Rallo. Financial support was provided by the Spanish

Ministerio de Educación y Ciencia (Project CTM2006-00315/TECNO) and the Entitat Metropolitana dels Serveis Hidràulics i de Tractament de Residus (Project Exp. 1086/05). 


\section{References}

Adani, F., Gigliotti, G., Valentini, F., Laraida, R., 2003. Respiration index determination: a comparative study of different methods. Compost Science and Utilization 11, 144151.

Adani, F., Confalonieri, R., Tambone, F., 2004. Dynamic respiration index as a descriptor of the biological stability of organic wastes. Journal of Environmental Quality 33, $1866-1876$.

Adani, F., Ubbiali, C., Genevini, P., 2006. The determination of biological stability of composts using the Dynamic Respiration Index: The results of experience after two years. Waste Management 26, 41-48.

ASTM, 1996. Standard Test Method for Determining the Stability of Compost by Measuring of Oxygen Consumption. American Society for Testing and Materials, D5975-96.

Barrena, R., Vázquez, F., Gordillo, M.A. Gea, T., Sánchez, A., 2005. Respirometric assays at fixed and process temperatures to monitor composting process. Bioresource Technology 96, 1153-1159.

Barrena, R., Vázquez, F., Sánchez, A., 2006. The Use of Respiration Indices in the Composting Process: A Review. Waste Management and Research 24, 37-47.

Bonhomme, M., Pavia, A., 1986. A new system for treatment of urban refuse: the Valorga process. Revue de l'Energie 385, 674-680.

Cooper, B.J., 2005. Stability (Biodegradability) Horizontal-7 WP4. Energy Research Center of the Netherlands. URL: http://www.ecn.nl/docs/society/horizontal/hor_desk_7_stability.pdf 
Cossu, R., Raga, R., 2007. Test methods for assessing the biological stability of biodegradable waste. Waste Management, available on-line: doi:10.1016/j.wasman.2007.01.014.

Eleazer, W.E., Odle, W.S., Wang, Y-S., Barlaz, M.A., 1997. Biodegradability of Municipal Solid Waste Components in Laboratory-Scale Landfills. Environmental Science and Technology 31, 911-917.

European Commission, 2001. Working document. Biological treatment of biowaste. 2nd draft. URL: http://www.compost.it/www/pubblicazioni_on_line/biod.pdf

Favoino, E., 2006. The EU legislation and the requirements following for national organic waste management strategies and policies. First Baltic Biowaste Conference, European Compost Network/Organic Recovery and Biological Treatment association.

URL: http://www.compostnetwork.info/bbc/downloads/3\%20Enzo\%20Favoino.pdf

Federal Government of Germany, 2001. Ordinance on environmentally compatible storage of waste from human settlements and on biological waste-treatment facilities of 20 February 2001.

Fernández, A., Sánchez, A., Font, X., 2005. Anaerobic co-digestion of a simulated organic fraction of municipal solid wastes and fats of animal and vegetable origin, Biochemical Engineering Journal 26, 22-28.

Fontanive, V., Effron, D., Tortarolo, F., Arrigo, N., 2004. Evaluation of parameters during composting of two contrasting raw materials. Compost Science and Utilization 12, 268-272. 
Fruteau, H., Desbois, S., Saint-Joly, C., 1997. Anaerobic digestion of municipal solid organic waste: Valorga full-scale plant in Tilburg, The Netherlands. Water Science and Technology 36, 457-462.

Gea, T., Barrena, R., Artola, A., Sánchez, A., 2004. Monitoring the Biological Activity of the Composting Process: Oxygen Uptake Rate (OUR), Respirometric Index (RI) and Respiratory Quotient (RQ). Biotechnology and Bioengineering 88, 520-527.

Godley, A., Muller, W., Frederickson, J., Barker, H., 2005. Comparison of the SRI and DR4 biodegradation test methods for assessing the biodegradability of untreated and MBT treated municipal solid waste. In: Kühle-Weidemeier, M, (ed.). International Symposium MBT 2005/Internationale Tagung MBA 2005. Cuvillier Verlag, Germany, pp. 548-559.

Hansen, T.L., Svard, A., Angelidaki, I., Schmidt, J.E., Jansen, J., Christensen, T.H., 2003. Chemical characteristics and methane potentials of source-separated and pre-treated organic municipal solid waste. Water Science and Technology 48, 205-208.

Hansen, T.L., Schmidt, J.E., Angelidaki, I., Marca, E., Jansen, J.L.C., Mosbæk, H., Christensen, T.H., 2004. Method for determination of methane potentials of solid organic waste. Waste Management 24, 393-400.

Ianotti, D.A., Pang, T., Toth, B.L., Elwell, D.L., Keener, H.M., Hoitink, H.A.J., 1993. A quantitative respirometric method for monitoring compost stability. Compost Science and Utilization 1, 52-65.

Komilis, D.P., Ham, R.K., 2003. The effect of lignin and sugars to the aerobic decomposition of solid wastes. Waste Management 23, 419-423.

Lasaridi, K.E., Papadimitriou, E.K., Balis, C., 1996. Development and demonstration of a thermogradient respirometer. Compost Science and Utilization 4, 53-61. 
Lasaridi, K.E., Stentiford, E.I., 1998. A simple respirometric technique for assessing compost stability. Water Research 32, 3717-3723.

Ligthart, J., Nieman, H., 2002. Proceedings of the Workshop on Harmonisation of Anaerobic Biodegradation, Activity and Inhibition Assays. EUR 20535 EN, European Commission Joint Research Centre.

Lissens, G., Vandevivere, P., De Baere, L., Biey, E.M., Verstraete, W., 2001. Solid waste digesters: process performance and practice for municipal solid waste digestion. Water Science and Technology 44, 41-48.

Luning, L., van Zundert, E.H.M., Brinkmann, A.J.F., 2003. Comparison of dry and wet digestion for solid waste. Water Science and Technology 48, 15-20.

Metcalf and Eddy, 2003. Wastewater Engineering: Treatment and Reuse (fourth ed.), McGraw-Hill, New York.

Papadimitriou, E.K., Balis, C., 1996. Comparative study of parameters to evaluate and monitor the rateo f a composting process. Compost Science and Utilization 4, 52-61.

Ros, M., García, C., Hernández, T., 2006. A full-scale study of treatment of pig slurry by composting: Kinetic changes in chemical and microbial properties. Waste Management 26, 1108-1118.

Scaglia, B., Tambone, F., Genevini, P., Adani, F., 2000. Respiration index determination: Dynamic and static approaches. Compost Science and Utilization 8, 90-98.

Tremier, A., de Guardia, A., Massiani, C., Paul, E., Martel, J.L., 2005. A respirometric method for characterising the organic composition and biodegradation kinetics and the temperature influence on the biodegradation kinetics, for a mixture of sludge and bulking agent to be co-composted. Bioresource Technology 96, 169-180. 
US Department of Agriculture and US Composting Council, 2001. Test methods for the examination of composting and compost. Edaphos International, Houston, Texas, USA. 


\section{Tables}

Table 1: Stability indices proposed in some European regulations.

\begin{tabular}{|c|c|c|c|c|c|c|}
\hline Reference* & Inoculation & Water Content & Temperature & $\begin{array}{c}\text { Test } \\
\text { duration }\end{array}$ & $\begin{array}{c}\text { Results } \\
\text { expression** }\end{array}$ & $\begin{array}{l}\text { Stability } \\
\text { limit }\end{array}$ \\
\hline \multicolumn{3}{|c|}{$\begin{array}{l}\text { European Commission, } 2001 \\
\text { Italia (Lombardia) (Favoino, 2006) }\end{array}$} & \multicolumn{3}{|c|}{ Biological treatment of biowaste $2^{\text {nd }} \mathrm{draft}$} & \\
\hline DRI & no & $\begin{array}{l}10-13 \mathrm{~kg}, 75 \% \text { water } \\
\text { holding capacity }\end{array}$ & self-heated & $<4$ days & $\underset{\mathrm{h}^{-1}}{\mathrm{mg} \mathrm{O} \mathrm{OS} \mathrm{VS}^{-1}}$ & 1000 \\
\hline $\mathrm{AT}_{4}$ & yes & $500 \mathrm{~g}, 50 \%$ moisture & $58^{\circ} \mathrm{C}$ & $\begin{array}{c}4 \text { days } \\
\text { expandable }\end{array}$ & $\mathrm{mg} \mathrm{O}_{2} \mathrm{~g} \mathrm{VS}^{-1}$ & 10 \\
\hline
\end{tabular}

Federal Government of Germany, 2001

Abfallablagerungsverordnung - AbfAblV

\begin{tabular}{|c|c|c|c|c|c|c|}
\hline $\mathrm{AT}_{4}$ & no & $\begin{array}{l}40 \mathrm{~g}, \text { saturation } \\
\text { + empty filtration }\end{array}$ & $20^{\circ} \mathrm{C}$ & $\begin{aligned} & 4 \text { days } \\
+ & \text { lag phase }\end{aligned}$ & $\mathrm{mg} \mathrm{O}_{2} \mathrm{~g} \mathrm{DM}^{-1}$ & 5 \\
\hline $\mathrm{GB}_{21}$ & yes & $\begin{array}{c}50 \mathrm{~g} \mathrm{DM} \\
+50 \mathrm{~mL} \text { inoculum } \\
\text { mL water } \\
\end{array}$ & $35^{\circ} \mathrm{C}$ & $\begin{aligned} & 21 \text { days } \\
+ & \text { lag phase }\end{aligned}$ & $\mathrm{L} \mathrm{kg} \mathrm{DM}^{-1}$ & 20 \\
\hline
\end{tabular}

Godley et al., 2005

United Kingdom Environment Agency

\begin{tabular}{|c|c|c|c|c|c|c|}
\hline $\mathrm{DR}_{4}$ & yes & $400 \mathrm{~g}, 50 \% \mathrm{MC}$ & $35^{\circ} \mathrm{C}$ & 4 days & $\begin{array}{l}\mathrm{mg} \mathrm{O}_{2} \mathrm{~g} \mathrm{DM}^{-1} \\
\text { or } \\
\mathrm{mg} \mathrm{O}_{2} \mathrm{~g} \mathrm{VS}^{-1}\end{array}$ & $\begin{array}{l}\text { No limit } \\
\text { proposed }\end{array}$ \\
\hline $\mathrm{BM}_{100}$ & yes & $\begin{array}{c}20 \mathrm{~g} \mathrm{VS} \\
+50 \mathrm{~mL} \text { inoculum } \\
\text { mL solution }\end{array}$ & $35^{\circ} \mathrm{C}$ & 100 days & $\mathrm{L} \mathrm{kg} \mathrm{VS}^{-1}$ & $\begin{array}{l}\text { No limit } \\
\text { proposed }\end{array}$ \\
\hline
\end{tabular}

* DRI, $\mathrm{AT}_{4}$ and $\mathrm{DR}_{4}$ are respiration indices (oxygen consumption), whereas $\mathrm{GB}_{21}$ and $\mathrm{BM}_{100}$ are anaerobic indices (biogas production)

** DM: Dry Matter; VS: Volatile Solids 
Table 2: Successive reductions of Respiration index and Biochemical methane potential (at 21 days) in selected points of the Mechanical-Biological treatment plant.

\begin{tabular}{ccccc}
\hline \multirow{2}{*}{$\begin{array}{c}\text { Point of the plant } \\
\end{array}$} & \multicolumn{2}{c}{ OFMSW } & \multicolumn{2}{c}{ MSW } \\
& & & (\% index reduction $)$ \\
\cline { 2 - 5 } & RI & BMP $_{21}$ & RI & BMP $_{21}$ \\
\hline Material from mechanical pretreatment & 43 & 45 & 28 & 0 \\
\hline Anaerobically digested material & 69 & 56 & 53 & 71 \\
\hline Composted material & 33 & 45 & 38 & 0 \\
\hline
\end{tabular}


Table 3: Respiration index and Biochemical methane potential (at 21 days) for final materials.

\begin{tabular}{|c|c|c|}
\hline \multirow{2}{*}{ Test } & Compost from & Stabilized material from \\
\hline & OFMSW & MSW \\
\hline \multicolumn{3}{|l|}{ Respiration index } \\
\hline $\begin{array}{l}\text { ( } \mathrm{g} \text { of oxygen consumed per } \mathrm{kg} \text { of dry } \\
\text { matter and per hour) }\end{array}$ & $1.00 \pm 0.21$ & $0.63 \pm 0.05$ \\
\hline \multicolumn{3}{|l|}{ Respiration index } \\
\hline $\begin{array}{l}\text { ( } \mathrm{g} \text { of oxygen consumed per } \mathrm{kg} \text { of volatile } \\
\text { solids and per hour) }\end{array}$ & $2.11 \pm 0.44$ & $1.19 \pm 0.09$ \\
\hline \multicolumn{3}{|l|}{ Biochemical methane potential } \\
\hline $\begin{array}{l}\text { (biogas volume }(\mathrm{L}) \text { produced at normal } \\
\text { conditions }(\mathrm{T}=273 \mathrm{~K}, \mathrm{P}=1 \text { bar) per } \mathrm{kg} \text { of } \\
\text { dry matter) }\end{array}$ & $38 \pm 3$ & $26 \pm 5$ \\
\hline \multicolumn{3}{|l|}{ Biochemical methane potential } \\
\hline $\begin{array}{l}\text { (biogas volume }(\mathrm{L}) \text { produced at normal } \\
\text { conditions }(\mathrm{T}=273 \mathrm{~K}, \mathrm{P}=1 \text { bar) per } \mathrm{kg} \text { of }\end{array}$ & $80 \pm 6$ & $49 \pm 9$ \\
\hline volatile solids) & & \\
\hline
\end{tabular}




\section{Legends to Figures}

Figure 1: Scheme of the Mechanical-Biological treatment plant. Triangles indicate sampling points.

Figure 2: Evolution of Respiration Index in the Mechanical-Biological treatment plant. Average of triplicates is presented jointly with standard deviation.

Figure 3: Evolution of Biochemical Methane Potential (21 days) in the MechanicalBiological treatment plant. Average of triplicates is presented jointly with standard deviation. Biochemical Methane Potential from inoculum has been deducted.

Figure 4: Correlation between Biochemical Methane Potential obtained at 21 days and final Biochemical Methane Potential. Average of triplicates is presented jointly with standard deviation. Biochemical Methane Potential from inoculum has been deducted.

Figure 5: Correlation between Biochemical Methane Potential obtained at 21 days and Respiration Index. Average of triplicates is presented jointly with standard deviation. Biochemical Methane Potential from inoculum has been deducted. 


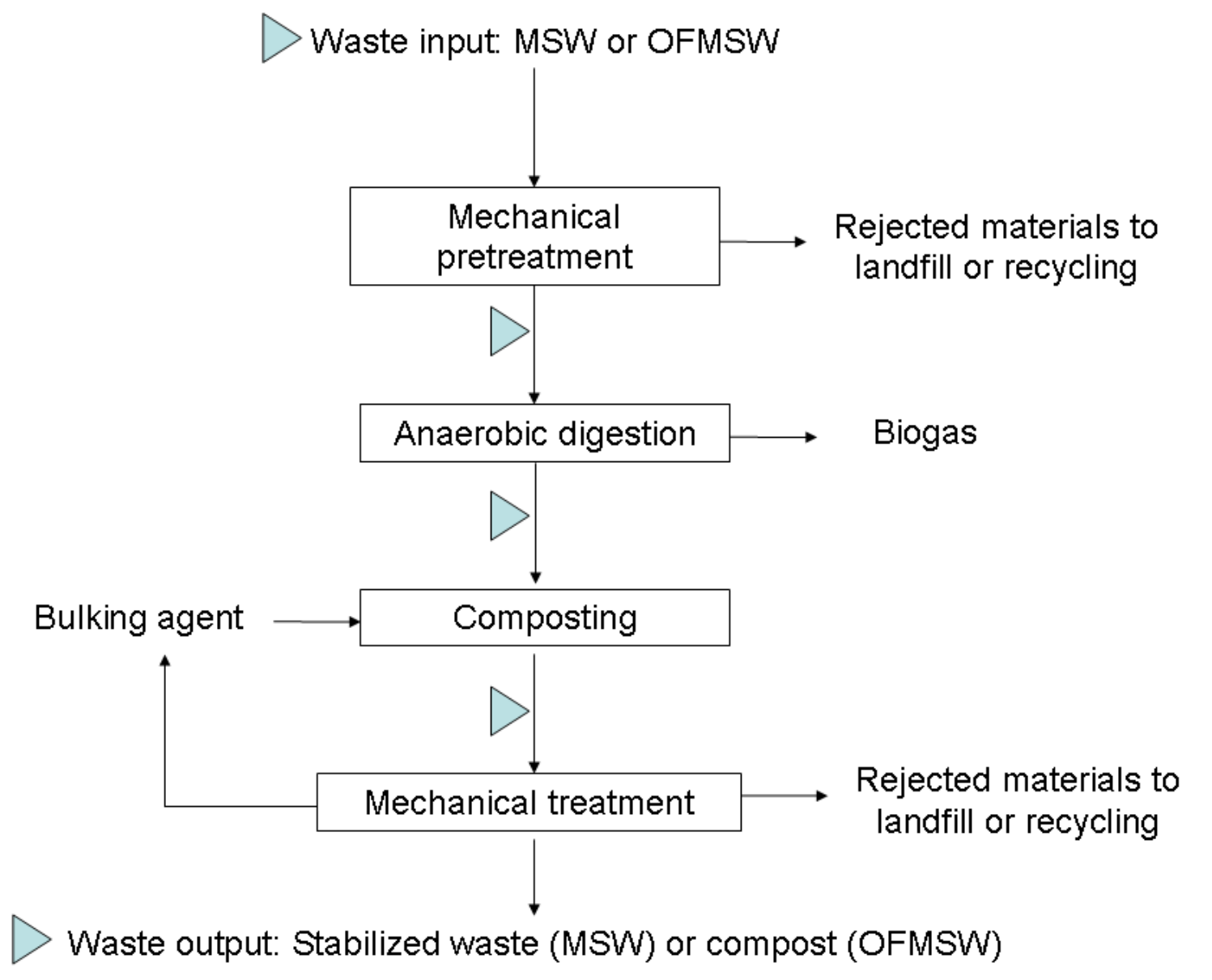


Figure 2: Ponsá et al.

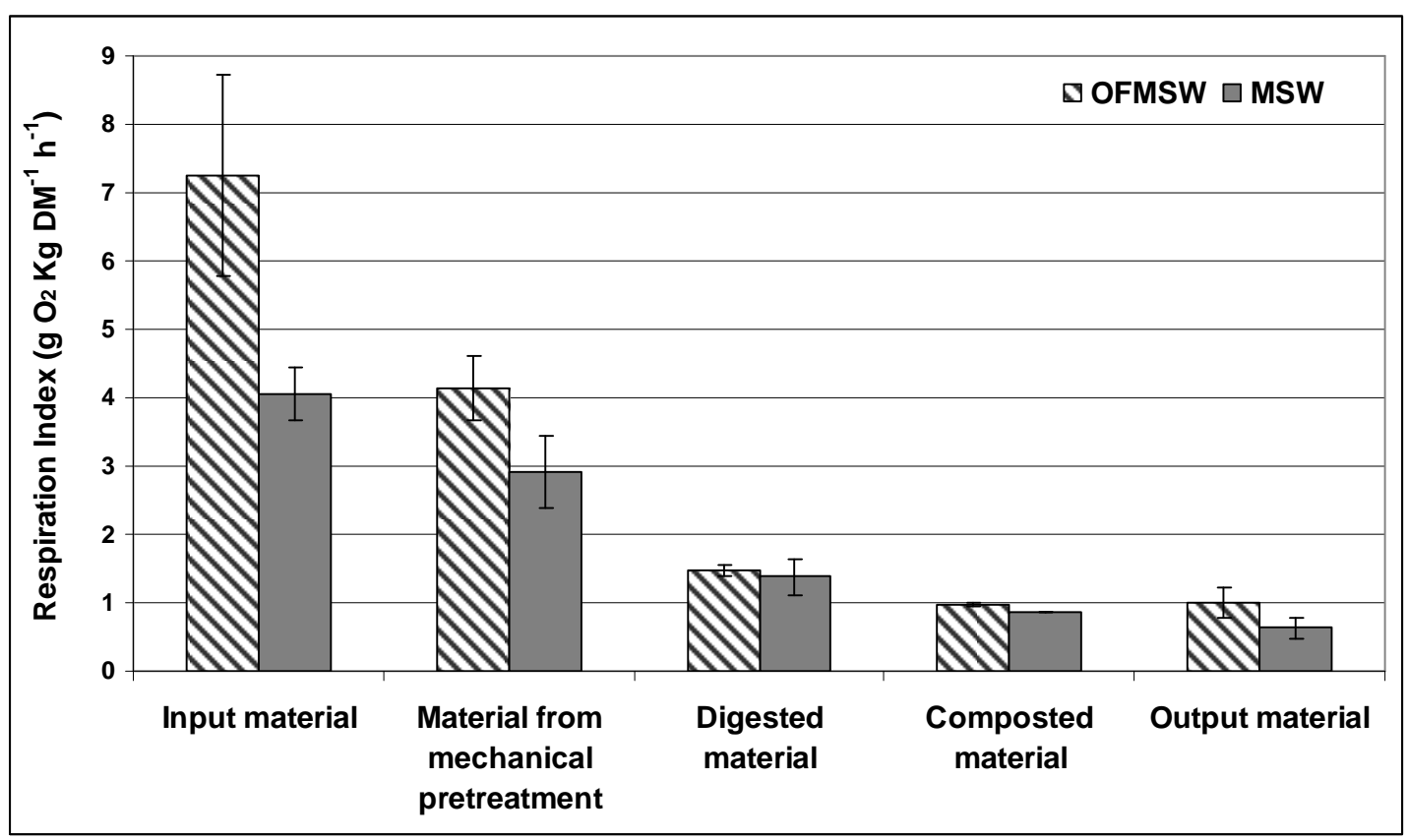


Figure 3: Ponsá et al.

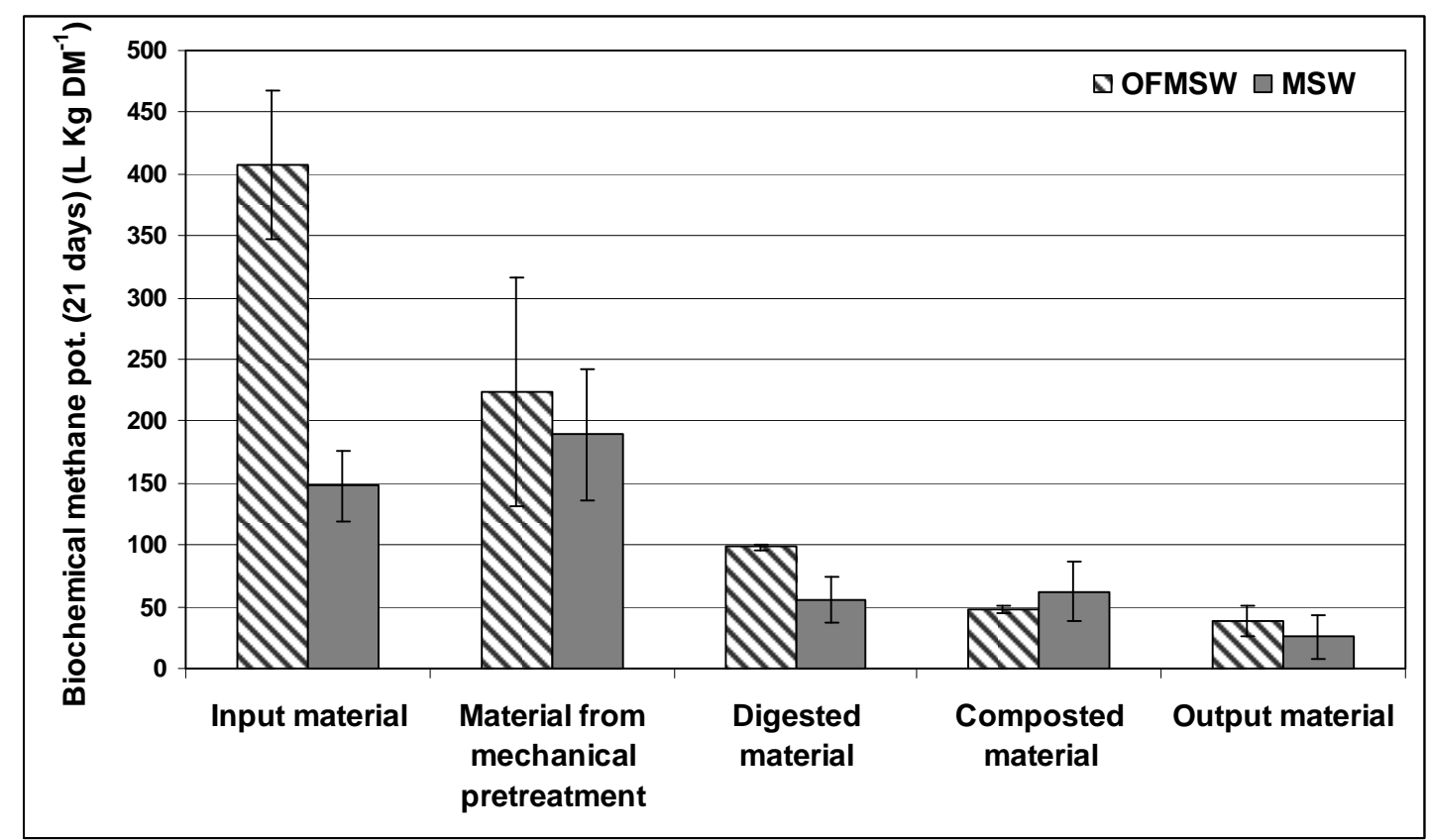


Figure 4: Ponsá et al.

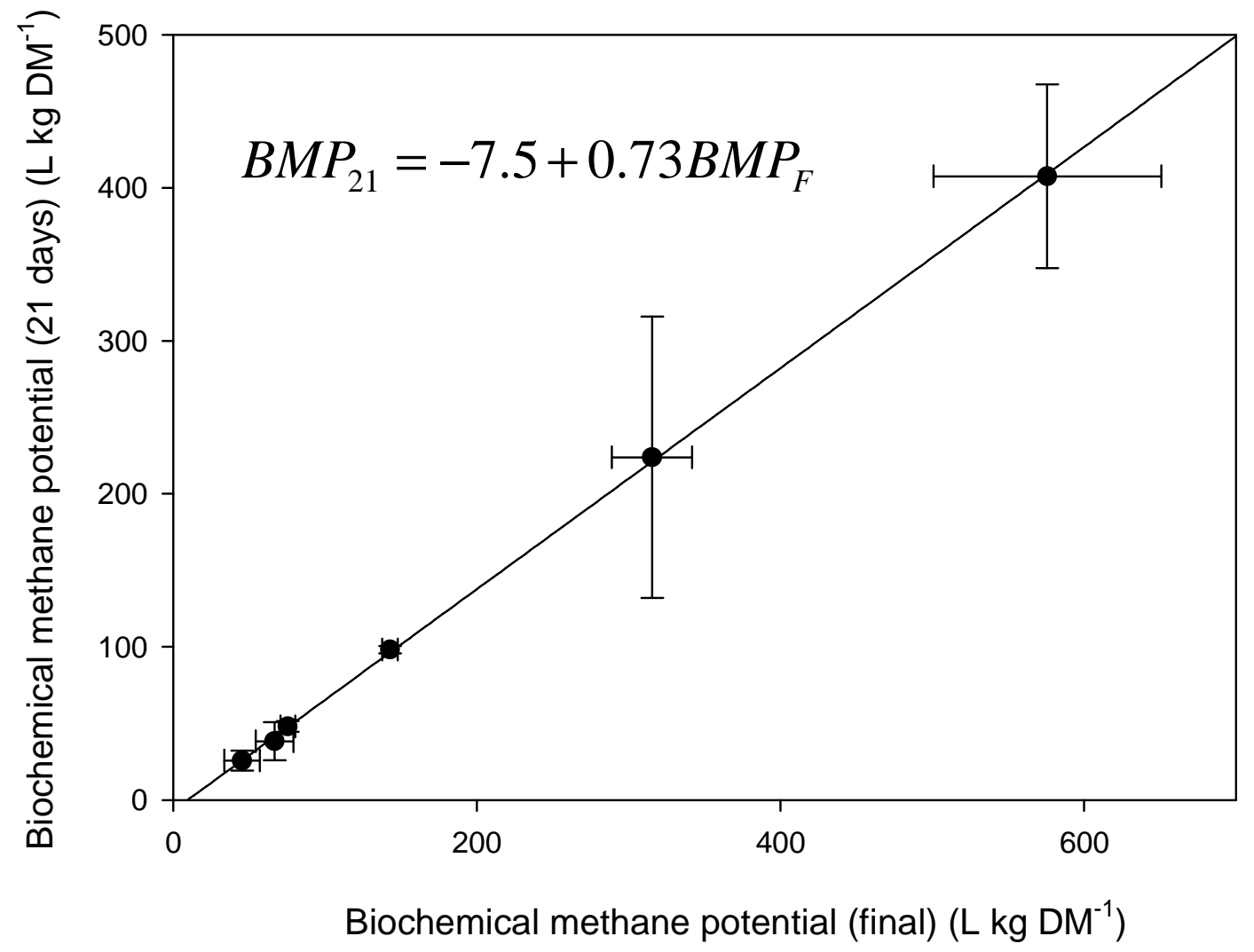


Figure 5: Ponsá et al.

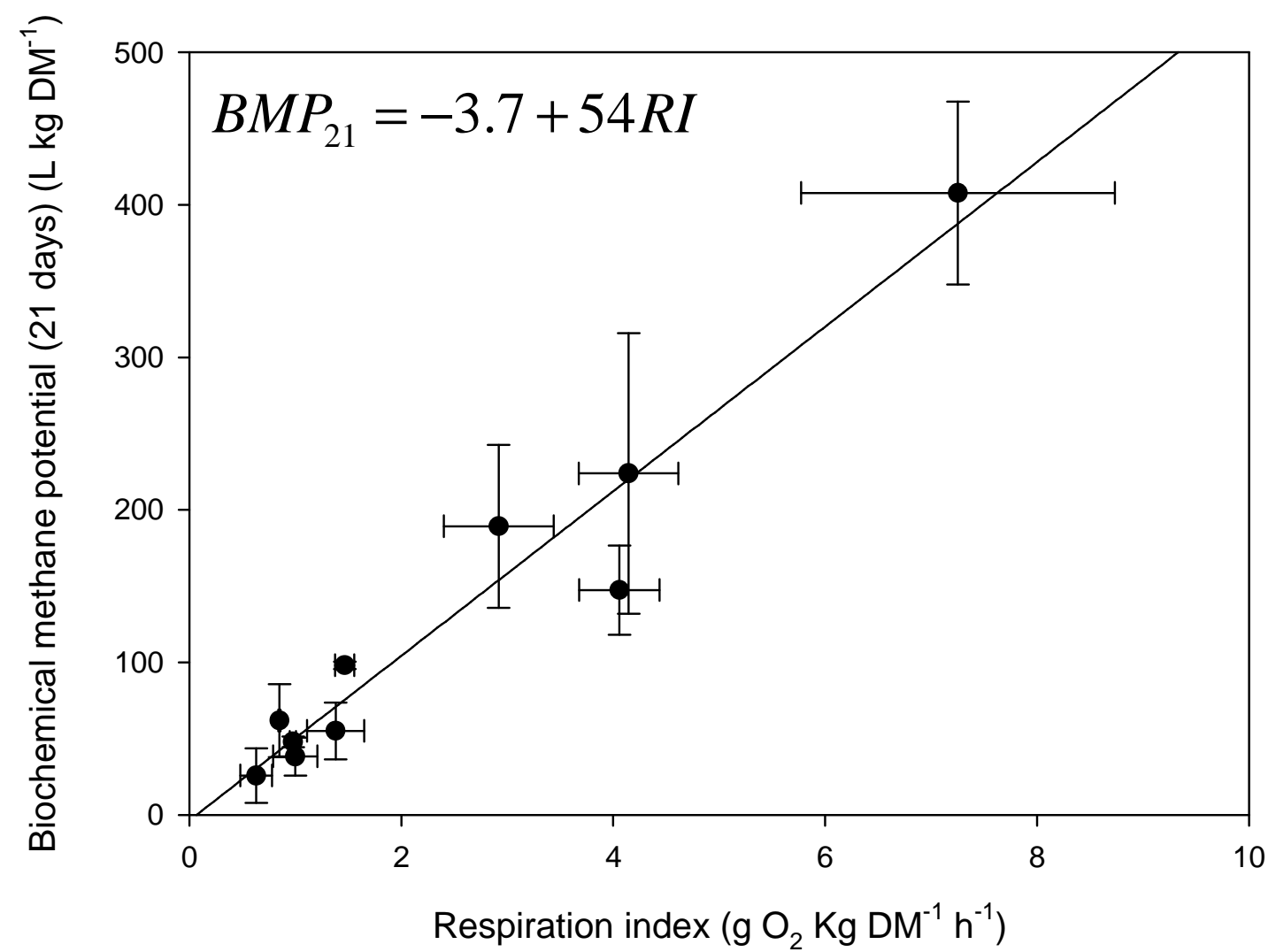

